\title{
Use of microarray technology to assess the time course of liver stress response after confinement exposure in gilthead sea bream (Sparus aurata L.)
}

\author{
Josep A Calduch-Giner1', Grace Davey², Alfonso Saera-Vila1', Benoit Houeix², Anita Talbot², Patrick Prunet33, \\ Michael T Cairns² and Jaume Pérez-Sánchez*1
}

\begin{abstract}
Background: Selection programs for growth and stress traits in cultured fish are fundamental to the improvement of aquaculture production. The gilthead sea bream (Sparus aurata) is the main aquacultured species in the Mediterranean area and there is considerable interest in the genetic improvement of this species. With the aim of increasing the genomic resources in gilthead sea bream and identifying genes and mechanisms underlying the physiology of the stress response, we developed a cDNA microarray for gilthead sea bream that is enriched by suppression substractive hybridization with stress and immunorelevant genes. This microarray is used to analyze the dynamics of gilthead sea bream liver expression profile after confinement exposure.

Results: Groups of confined and control juvenile fish were sampled at 6, 24, 72 and $120 \mathrm{~h}$ post exposure. GeneSpring analyses identified 202 annotated genes that appeared differentially expressed at least at one sampling time $(P<0.05)$. Gene expression results were validated by quantitative PCR of 10 target genes, and K-means clustering of differently expressed genes identified four major temporal gene expression profiles. Set 1 encompassed a rapid metabolic readjustment with enhanced uptake and intracellular transport of fatty acids as metabolic fuels. Set 2 was associated with a wide variety of tissue repair and remodeling processes that were mostly mediated by the stress response of the endoplasmic reticulum (ER). Sets 3 and 4 encompassed the re-establishment of cellular homeostasis with increased intracellular trafficking and scavenging of reactive oxygen species (ROS), accompanied by a bidirectional regulation of the immune system and a general decline of ROS production.

Conclusions: Collectively, these findings show the complex nature of the adaptive stress response with a clear indication that the ER is an important control point for homeostatic adjustments. The study also identifies metabolic pathways which could be analyzed in greater detail to provide new insights regarding the transcriptional regulation of the stress response in fish.
\end{abstract}

\section{Background}

Selective breeding to ameliorate stress susceptibility has long been established in terrestrial vertebrates of economical relevance [1], but cultured fish are essentially nondomesticated species and selection programs for growth and stress traits are still in their infancy $[2,3]$. In salmonids, however, a genetic component exists for the stress-mediated response of cortisol [4-6], and selective breeding for

\footnotetext{
*Correspondence: jperez@iats.csic.es

1 Fish Nutrition and Growth Endocrinology Group, Department of Biology, Culture and Pathology of Marine Fish Species, Institute of Aquaculture Torre de la Sal (CSIC), 12595 Ribera de Cabanes, Castellón, Spain

Full list of author information is available at the end of the article
}

low- and high-cortisol responders has been performed in rainbow trout (Oncorhynchus mykiss) after handling and exposure to a confinement stressor [7,8]. In carp (Cyprinus carpio), a high heritability has also been found for the stress-related increases in plasma cortisol levels after cold shock exposure [9]. Progeny of gilthead sea bream (Sparus aurata) from parents selected for low- or high-cortisol response also show divergent responses [10], although in this species low-cortisol responders can be more sensitive to handling and confinement [11]. This finding is indicative that parameters other than plasma cortisol levels must be considered to fully understand the regulation of stress 
responsiveness and susceptibility. For instance, the cortisol peak is indicative in gilthead sea bream of the intensity and duration of stressor when data found in the literature are compared, but a bimodal rise after acute stress confinement has been reported by some authors $[12,13]$, which would be indicative of some exhaustion of the hypothalamic-pituitary-interrenal axis. By contrast, protein and transcript levels of glucose-regulated protein 75 (GRP75/mortalin), a mitochondrial chaperone of the HSP70 family, are increased by both acute and chronic stress confinement in liver tissue [14]. In addition, transcriptional and promoter analyses of duplicated growth hormone receptors (GHR) indicate that GHR-II rather than GHR-I is a stress sensitive gene in gilthead sea bream $[12,15]$.

With the advent of "omic" technologies, a significant portion, if not all, of the set of transcripts, proteins or metabolites that a study wishes to consider can be determined in one assay. cDNA- and oligo-arrays are in fact powerful tools for the gene expression profiling of many thousands of genes, and various zebrafish (Danio rerio), medaka (Oryzias latipes) and fugu (Takifugu rubripes) microarrays have been developed for toxicogenomics, immunity, development and environmental stress research [16]. Genomic resources in fish species of interest in aquaculture are also continuously growing and species-specific microarrays are now available in salmonids [17-21], flatfish [22,23] and catfish $[24,25]$. In the case of gilthead sea bream, a highly cultured fish throughout the Mediterranean, a first microarray with 10,176 clones from a cDNA library of embryonic and larval origin has been developed by Sarropoulou et al. [26] to analyze gene expression profile during early development and cortisol treatment. Recently, a second microarray has been constructed and used in developmental studies by Ferraresso et al. [27]. The aim of the current study is to gain more understanding of the physiology of the stress response using a third gilthead sea bream microarray, enriched by subtractive hybridization (SSH) with stress and immunorelevant genes. Time series analyses of data revealed the complexity of the adaptive stress response and underscore the utility of this custom-made array to analyze homeostatic adjustments to stress. This understanding will have practical implications on fish culture and management.

\section{Results}

\section{Microarray construction}

A total of 36,870 gilthead sea bream nucleotide sequences were available for the construction of a cDNA sea bream microarray. Most were sequenced either from tissue EST collections made available by the Consortium of Marine Genomics Europe or from SSH libraries constructed, as described herein, from target tissues after stress and parasite challenges (for details see Construction of SSH libraries in Methods section), and some were obtained from public databases. The number of assembled sequences was 19,069: 12,409 singletons and 6,660 contigs with two or more ESTs in depth [http://www.sigenae.org/aquafirst]. Clone sequences derived from confinement and pathogen SSH libraries [GenBank: FP331359-FP339571, FP339630FP340170] were represented in 4,851 unique sequences, and most of these $(3,161)$ were novel gilthead sea bream sequences. The entire list of assembled sequences was annotated by BLASTX search on the UniProt database and 6,064 unique sequences showed a significant similarity (E value $<10^{-5}$ ) to known genes. Taking into account contigs that were homologous to the same gene, the final number of unique genes on the microarray was 4,876 . This platform has been assigned the Gene Expression Omnibus (GEO) accession number GPL8467. It was possible to assign gene ontology (GO) annotations to 6,193 features and the most prevalent GO categories at level 3 (biological processes and molecular functions) are summarized in Table 1.

\section{Expression analysis}

To analyze the time course of the response to stress, fish of $110-130 \mathrm{~g}$ body weight were sampled at $6,24,72$ and $120 \mathrm{~h}$ after transfer from $500-1$ tanks $\left(8-10 \mathrm{Kg} / \mathrm{m}^{3}\right)$ to cylinder net baskets of $10-1$ volume $\left(117-123 \mathrm{Kg} / \mathrm{m}^{3}\right)$. Given this body weight, the rearing density for control fish is near to optimum for gilthead sea bream. The analysis of the hepatic gene expression profile after 10 -fold increase in fish density (the confinement stressor) identified 660 unique transcripts as differentially expressed genes $(\mathrm{P}<0.05$, one-way ANOVA by time and condition). Among these, 202 transcripts were annotated genes, and the time course of changes in up- and down-regulated genes at each sampling point is shown in Figure 1A. After 6 h of confinement, a relative low number of genes (54) were differentially expressed. The maximal number of differentially expressed genes (189 genes) was attained at $24 \mathrm{~h}$, and after that the number of differentially expressed genes decreased progressively to 77 at $120 \mathrm{~h}$. Analysis by Blast2GO revealed the involvement of these differentially expressed genes in a wide variety of processes including among others biosynthetic processes, transport, cell communication, response to stress and regulation of metabolism and catabolism (Figure 1B).

K-means clustering of differentially expressed genes identified four major expression patterns displaying distinct temporal profiles (Figure 2). The first cluster set was composed of 21 genes that showed an early up-regulation at $6 \mathrm{~h}$ after confinement. The second cluster set was composed of 51 genes that displayed a delayed and strong up-regulation at $24 \mathrm{~h}$ with a fast recovery to control levels by $120 \mathrm{~h}$. The third cluster set was composed of 57 genes with a late but more sustained stress induction that was still evident after $120 \mathrm{~h}$ of confinement exposure. The fourth cluster set was 
Table 1: Top biological and molecular GO terms (level 3) on the gilthead sea bream cDNA microarray.

\begin{tabular}{|c|c|}
\hline $\begin{array}{l}\text { GO description (biological } \\
\text { process) }\end{array}$ & Features \\
\hline Primary metabolic process & 1855 \\
\hline Cellular metabolic process & 1843 \\
\hline $\begin{array}{l}\text { Macromolecule metabolic } \\
\text { process }\end{array}$ & 1523 \\
\hline $\begin{array}{l}\text { Regulation of biological } \\
\text { process }\end{array}$ & 806 \\
\hline $\begin{array}{l}\text { Cellular component } \\
\text { organization and biogenesis }\end{array}$ & 736 \\
\hline Transport & 693 \\
\hline Regulation of cellular process & 678 \\
\hline Cell communication & 549 \\
\hline Biosynthetic process & 484 \\
\hline $\begin{array}{l}\text { Multicellular organismal } \\
\text { development }\end{array}$ & 481 \\
\hline $\begin{array}{l}\text { Anatomical structure } \\
\text { development }\end{array}$ & 470 \\
\hline $\begin{array}{l}\text { Regulation of metabolic } \\
\text { process }\end{array}$ & 374 \\
\hline $\begin{array}{l}\text { Cellular developmental } \\
\text { process }\end{array}$ & 359 \\
\hline Response to stress & 293 \\
\hline Catabolic process & 280 \\
\hline Cellular localization & 265 \\
\hline $\begin{array}{l}\text { Establishment of cellular } \\
\text { localization }\end{array}$ & 263 \\
\hline Cell development & 261 \\
\hline $\begin{array}{l}\text { Anatomical structure } \\
\text { morphogenesis }\end{array}$ & 250 \\
\hline Macromolecule localization & 230 \\
\hline $\begin{array}{l}\text { Establishment of protein } \\
\text { localization }\end{array}$ & 209 \\
\hline $\begin{array}{l}\text { Generation of precursor } \\
\text { metabolites and energy }\end{array}$ & 200 \\
\hline $\begin{array}{l}\text { Regulation of biological } \\
\text { quality }\end{array}$ & 182 \\
\hline Cell cycle & 178 \\
\hline Death & 166 \\
\hline Cell proliferation & 165 \\
\hline $\begin{array}{l}\text { Nitrogen compound } \\
\text { metabolic process }\end{array}$ & 159 \\
\hline $\begin{array}{l}\text { Response to external } \\
\text { stimulus }\end{array}$ & 157 \\
\hline $\begin{array}{l}\text { Response to chemical } \\
\text { stimulus }\end{array}$ & 146 \\
\hline
\end{tabular}

Table 1: Top biological and molecular GO terms (level 3) on the gilthead sea bream cDNA microarray. (Continued)

Cell cycle process
GO description (molecular
function)

137

\begin{tabular}{lc}
\hline Protein binding & 1452 \\
Hydrolase activity & 688 \\
lon binding & 666 \\
Nucleic acid binding & 562 \\
Nucleotide binding & 511 \\
Transferase activity & 473 \\
Oxidoreductase activity & 342 \\
Substrate-specific & 247 \\
transporter activity & \\
Signal transducer activity & 208 \\
Transmembrane transporter & 195
\end{tabular}

activity

Cofactor binding

Enzyme inhibitor activity 109

Ligase activity $\quad 98$

Transcription factor activity $\quad 95$

Structural constituent of $\quad 93$

ribosome

Lipid binding $\quad 84$

Enzyme activator activity $\quad 74$

Lyase activity $\quad 64$

Isomerase activity $\quad 57$

Translation factor activity, $\quad 54$

nucleic acid binding

Transcription activator $\quad 52$

activity

Transcription cofactor 52

activity

GTPase regulator activity 52

Vitamin binding 51

Tetrapyrrole binding $\quad 50$

composed of 54 genes that showed a persistent down-regulation at $24 \mathrm{~h}$ through to $120 \mathrm{~h}$ of confinement exposure.

In each K-means cluster, FatiGO analysis for the overrepresentation of GO-terms suggested the enrichment in some biological processes, although adjusted P-values (Fisher exact test) did not fall in the range of statistical significance $(\mathrm{P}<0.05)$. The entire list of up-regulated genes (sets 1,2 and 3) is shown in Additional file 1. The most distinctive feature of set 1 is the presence of genes involved in tissue uptake and intracellular transport of fatty acids (lipo- 


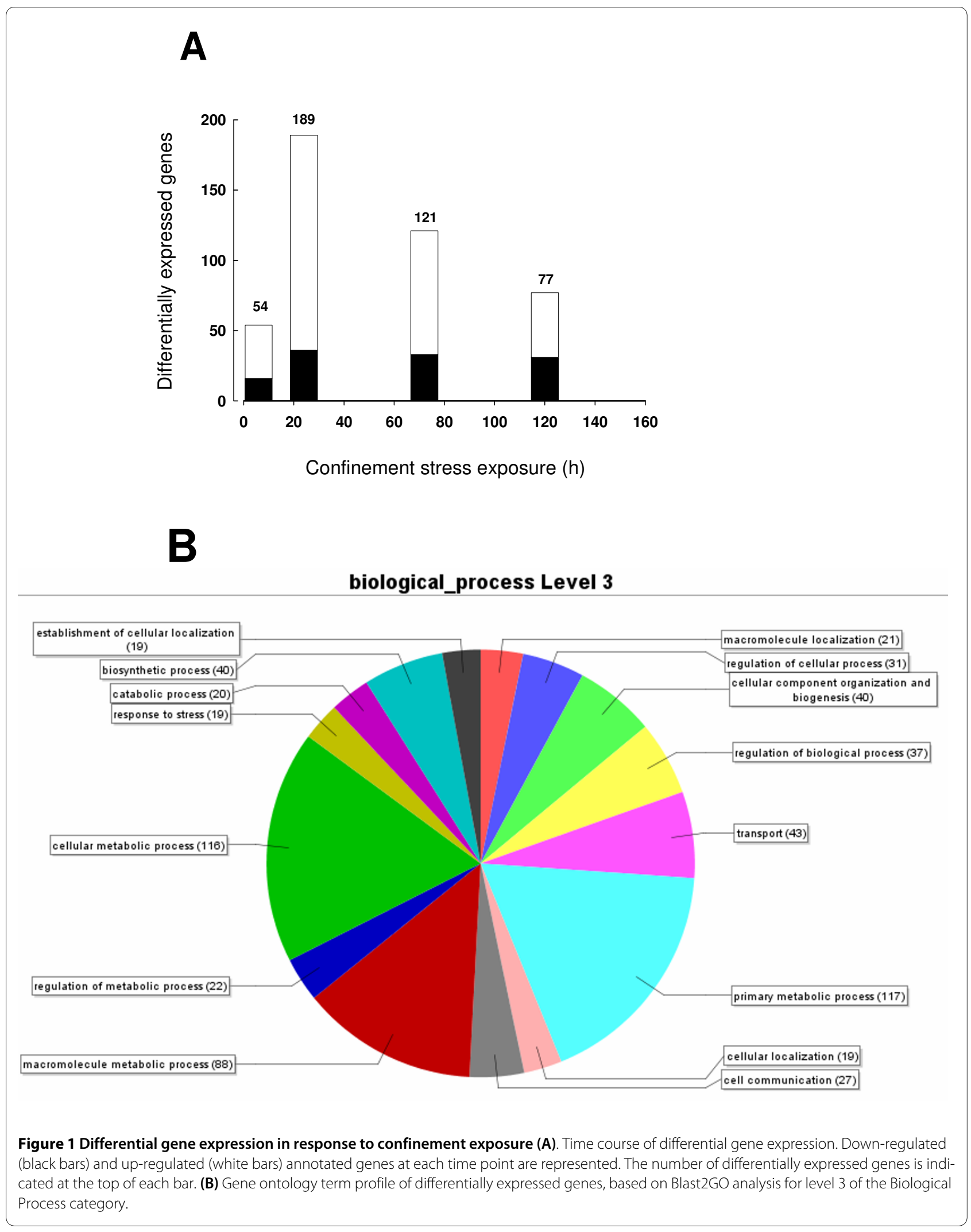



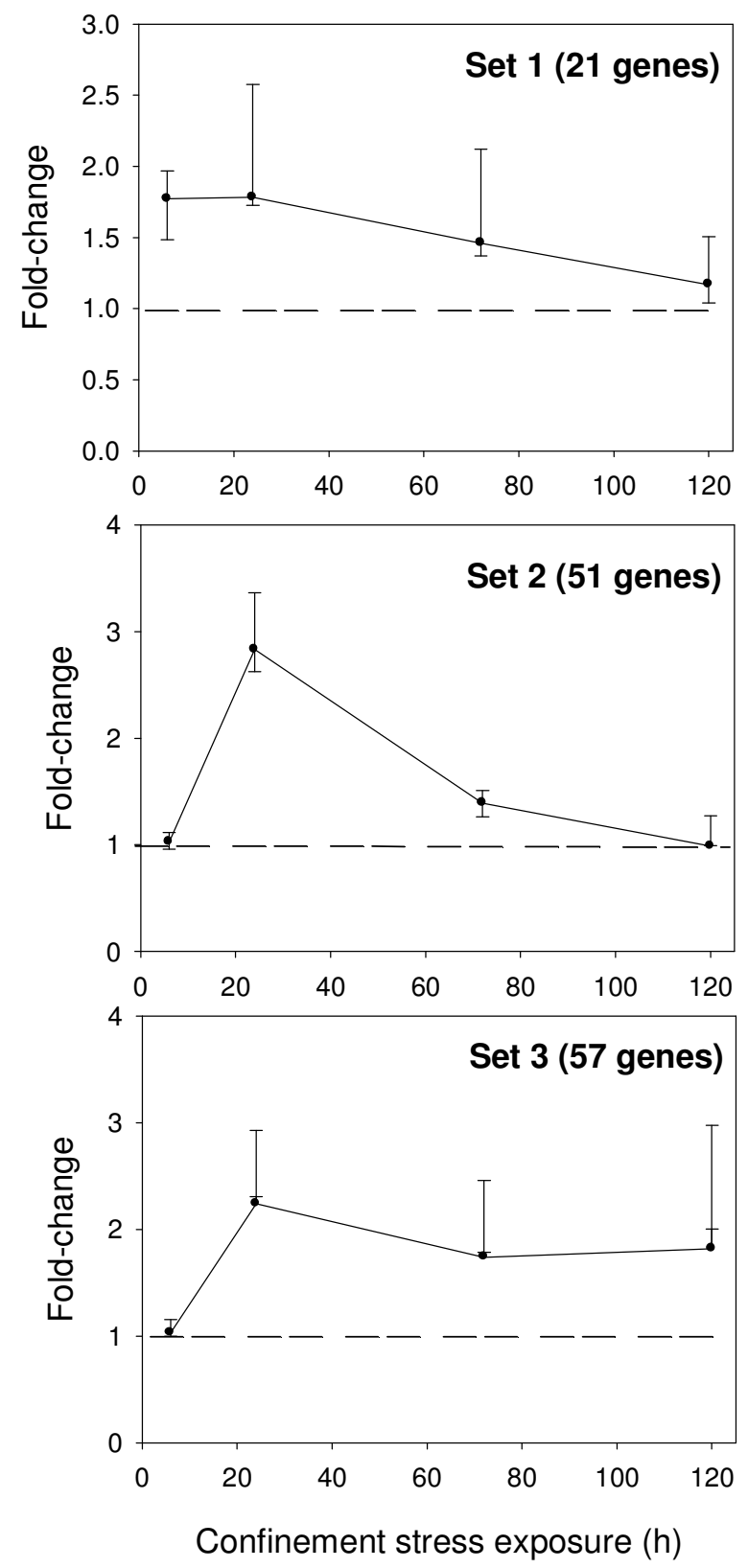

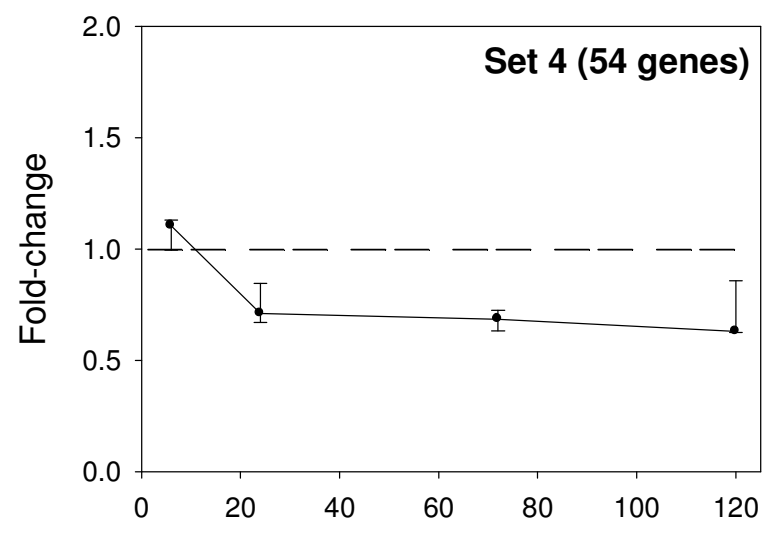

Confinement stress exposure $(\mathrm{h})$

Figure 2 Fold-change expression profiles of gene clusters. At each time point, median values ( $95 \%$ confidence interval) of fold-change are represented.

protein lipase, heart-type fatty acid-binding protein, acid cholesteryl ester hydrolase), cysteine metabolism (cystathionine $\beta$-synthase, cysteine dioxygenase) and oxidoreductase activity (L-2-hydroxyglutarate dehydrogenase, metalloreductase STEAP2) in addition to a repertoire of genes related to the reset of stress response (protein phosphatase 2C homolog 1), apoptosis (cell death-inducing DFFA-like effector protein C, ecto-ADP-ribosyltransferase 4) and cell proliferation (e.g. BolA-like protein 2, inter- feron-related developmental regulator 1). Many genes of set 2 are involved in tissue repair and remodeling processes through the enhancement of the protein folding capacity of the endoplasmic reticulum (ER) and ER-associated protein degradation. This set includes among other enzymes and chaperones, derlin-1, ubiquitin-conjugating enzyme E2 N, ubiquitin-protein ligase D3, $94 \mathrm{kDa}$ glucose-regulated protein, and $170 \mathrm{kDa}$ glucose-regulated protein. This cluster also comprises a large set of genes involved in the regula- 
tion of transcription and translation (e.g. zinc finger proteins 9,330 and 479 , transcription factor Sp1, threonyltRNA synthetase), as well as cholesterol and sterol biosynthesis (arachidonate lipoxygenase 3, $\Delta 14$-sterol reductase, diphosphomevalonate decarboxylase, farnesyl diphosphate synthetase and ergosterol biosynthetic protein 28). Set 3 is abundant in inhibitors of protein breakdown (e.g. $\alpha$-2-macroglobulin, Hsp70-binding protein 1), protein targeting and glycosylation (e.g. signal recognition particle $54 \mathrm{kDa}$ protein, ribophorin I) and vesicle-mediated transport (e.g. clathrin assembly protein complex 1 , clathrin heavy chain 1, ras-related proteins Rab-10, 1A and 6A). Also in set 3, a number of genes participate in sterol metabolism, cytoskeleton rearrangements (e.g. coronin-1C, tubulin $\alpha$-chain), immune response (e.g. complement pathway, cyclosporine A-binding protein, hepcidin) and antioxidant defense through their involvement in iron metabolism (ferroxidase/ ceruloplasmin), oxygen transport (hemoglobin subunit $\beta$ ) and glutathione synthesis and recycling (cystathionine $\gamma$ lyase, glycine N-methyltransferase, GDH/6PGL endoplasmic bifunctional protein, cytoplasmic isocitrate dehydrogenase).

Down-regulated genes (set 4) are listed in Table 2 and reveal a metabolic readjustment mediated by the depletion of many proteins and enzymes involved in amino acid and nucleotide metabolism (e.g. urate oxidase, aspartate aminotransferase, glycine decarboxylase), glycolysis (fructosebiphosphate aldolase), mitochondrial respiration (NADHubiquinone oxidoreductase subunit B14.5b, cytochrome c oxidase subunit IV isoform 2), xenobiotic metabolism (alcohol dehydrogenase 1, glutathione S-transferase 3, cytochrome $\mathrm{P} 450$ family, monoamine oxidase, retinol-binding protein II) and immune response through a wide range of processes: acute immune response ( $\alpha$-2-HS-glycoprotein), antigen binding and processing (Ig heavy chain Mem5, histocompatibility complex), lectin pathway (fucolectin-1), histamine metabolism (histamine-N-methyltransferase), and inflammatory and interferon signaling (macrophage migration inhibitory factor, interferon regulatory factor 8 ).

\section{Real-time PCR validation}

The 10 target genes selected for validation of microarray data covered the full range of signal intensity and foldchange results. Their hepatic expression profiles determined by real-time PCR are represented in Figure 3A. In the range of low and intermediate fold-changes, overall data revealed a good correlation between real-time PCR and microarray results (Figure 3B). However, the dynamic range of the microarray is lower than that of the PCR assay, and gene expression changes are under-estimated by the microarray in the upper range of down- and up-regulated changes $(0.2>$ fold-change $>10)$, which becomes evident when data on Figure 3B are represented in a linear scale instead of a logarithmic scale.

\section{Discussion}

The SSH technique has been widely used in various animal models to identify tissue-specific or differentially expressed genes between populations of interest [28]. The sensitivity of this methodology is lower than previously envisaged, but in gilthead sea bream this approach has been used successfully for the identification of differentially expressed genes after estradiol treatment [29] and nodavirus infection [30]. In the present study, this technique has also proved successful for the isolation of a relatively high number of novel annotated sequences (more than $20 \%$ of the total) which have been used to construct a new gilthead sea bream microarray, contributing to the improvement of genomic resources for a marine fish highly cultured throughout the Mediterranean.

In fish and higher vertebrates, the stress response involves changes in plasma glucocorticoids, catecholamines and other classical stress parameters [31,32]. In the case of gilthead sea bream, endocrine and metabolic responses to handling and confinement exposure have been analyzed in some detail [10,33-36], but this is the first attempt at an extensive transcriptional study to monitor the dynamics of the stress response. Given the central role of liver in many homeostatic processes, this organ was targeted for the study and cluster analysis of differentially expressed genes identifying four sets of either up- (sets 1,2 and 3) or down-regulated (set 4) genes. As summarized in Figure 4, this gene expression profiling shows the complexity of the stress response with early, delayed and persistent adaptive responses which underscore cell-tissue specific adjustments: a) rapid enhancement of energy supply, b) tissue repair and remodeling processes and c) re-establishment of redox balance.

Metabolic rates are increased by stress [37], and the concomitant high energy demand is supported by a rapid mobilization and enhanced tissue uptake of metabolic fuels. Lipids are the most important energy source in carnivorous fish [38,39], and the stress up-regulation of genes involved in lipid transport and fatty acid metabolism points toward the increased availability of energy substrates. At vascular surfaces, lipoprotein lipase (LPL) catalyzes the hydrolysis of circulating triglyceride-rich lipoproteins acting as a limiting enzyme on tissue fatty acid uptake [40]. In gilthead sea bream, the up-regulated expression of LPL is a well documented phenomenon in fish with signs of essential fatty acid deficiencies leading to increase lipid deposition rates in the liver tissue $[41,42]$. In the present study therefore, the increased expression of hepatic LPL as part of the early stress response was not surprising. Similarly, handling stress also induces the rapid up-regulation of hepatic LPL in rainbow trout [43]. 
Table 2: K-means clustering of down-regulated genes (Set 4).

\begin{tabular}{|c|c|c|c|c|}
\hline Putative Id & Uniprot Accession & Score & Description & $\begin{array}{l}\text { Fold change } \\
(6,24,72,120 \mathrm{~h})\end{array}$ \\
\hline \multicolumn{5}{|c|}{ Set 4 (54 genes): Delayed and persistent down-regulation } \\
\hline $\begin{array}{l}\text { Peroxisome proliferator-activated } \\
\text { receptor-binding protein }\end{array}$ & Q15648 & $7 \mathrm{E}-25$ & Transcription & $-1.08,-1.64,1.03,-1.28$ \\
\hline RNA polymerase B transcription factor 3 & P20290 & $2 \mathrm{E}-71$ & Transcription & $-1.22,1.18,1.01,-2.17$ \\
\hline Thioredoxin-binding protein 2 & Q9H3 M7 & $3 \mathrm{E}-22$ & Transcriptional repression & $-1.17,-1.85,-1.21,-1.08$ \\
\hline $\begin{array}{l}\text { Probable ATP-dependent } \\
\text { RNA helicase DDX48 }\end{array}$ & Q91VC3 & $1 \mathrm{E}-140$ & RNA splicing & $-1.16,1.13,1.15,-2.17$ \\
\hline $\begin{array}{l}\text { Cleavage and polyadenylation } \\
\text { specificity factor } 5\end{array}$ & Q7T3C6 & $1 \mathrm{E}-125$ & mRNA processing & $-1.21,1.42,-1.05,-2.56$ \\
\hline 40 S ribosomal protein $\$ 25$ & Q6Q311 & $5 \mathrm{E}-30$ & Translation & $-1.14,1.01,1.13,-2.63$ \\
\hline $\begin{array}{l}\text { Translation initiation factor } \\
\text { elF-2B subunit gamma }\end{array}$ & Q4R6T3 & $8 \mathrm{E}-6$ & Translation & $-1.03,-3.85,-2.78,-1.51$ \\
\hline Phospholipase A2 & P00592 & $1 E-31$ & Signal transduction & $1.09,-1.24,-1.45,-3.03$ \\
\hline Phospholipase D & 017405 & $4 E-27$ & Signal transduction & $1.04,-1.37,-1.21,1.24$ \\
\hline $\begin{array}{l}\text { Calcium/calmodulin-dependent } \\
\text { protein kinase type II } \delta \text { chain }\end{array}$ & Q13557 & $2 E-70$ & $\begin{array}{l}\text { Signal transduction/regulation } \\
\text { of cell growth }\end{array}$ & $-1.21,-1.77,-1.82,-1.24$ \\
\hline $\begin{array}{l}\text { Proto-oncogene tyrosine-protein } \\
\text { kinase receptor ret }\end{array}$ & P35546 & $1 E-25$ & Signal transduction/development & $-1.10,-1.11,-1.21,-1.92$ \\
\hline $\begin{array}{l}\text { Translationally-controlled } \\
\text { tumor protein }\end{array}$ & Q9DGK4 & $2 E-57$ & Apoptosis, negative regulator & $-1.43,1.16,1.08,-2.78$ \\
\hline Trypsin & P35034 & $2 \mathrm{E}-37$ & Proteolysis/digestion & $-1.12,-1.06,-1.15,-2.94$ \\
\hline Elastase-1 & Q7SIG3 & $1 \mathrm{E}-112$ & Proteolysis/pancreas & $-1.21,-1.49,-1.47,-2.17$ \\
\hline $\begin{array}{l}\text { a-1-antitrypsin-like } \\
\text { protein CM55-MS }\end{array}$ & O54758 & $3 \mathrm{E}-69$ & Protease inhibitor/extracellular & $-1.13,-1.25,-1.52,-1.01$ \\
\hline Nucleolar GTP-binding protein 1 & Q9BZE4 & $4 \mathrm{E}-41$ & $\begin{array}{l}\text { Negative regulation of } \\
\text { protein ubiquitination }\end{array}$ & $-1.01,1.16,-1.05,-3.57$ \\
\hline Rotamase 1B & P68106 & $2 \mathrm{E}-52$ & Protein folding/cytoplasm & $1.42,-2.63,-2.17,-1.27$ \\
\hline $\begin{array}{l}\text { Signal sequence } \\
\text { receptor subunit a }\end{array}$ & P45433 & $1 \mathrm{E}-101$ & Protein folding/ER & $-1.27,1.87,1.01,-3.03$ \\
\hline $\begin{array}{l}\text { Adenylosuccinate } \\
\text { synthetase isozyme } 2\end{array}$ & P46664 & $8 E-16$ & Nucleotide biosynthesis & $-1.03,-1.64,-1.57,-1.64$ \\
\hline Nicotinamide riboside kinase 2 & Q9NPI5 & $1 E-73$ & Nucleotide biosynthesis & $-1.30,1.03,1.03,-2.78$ \\
\hline
\end{tabular}


Table 2: K-means clustering of down-regulated genes (Set 4). (Continued)

\begin{tabular}{|c|c|c|c|c|}
\hline $\begin{array}{l}\text { Liver-specific } \\
\text { uridine phosphorylase }\end{array}$ & Q8CGR7 & $1 E-84$ & Nucleotide catabolism & $1.51,-1.09,-1.72,2.22$ \\
\hline $\begin{array}{l}\text { Malonate-semialdehyde } \\
\text { dehydrogenase [acylating] }\end{array}$ & Q07536 & $1 E-131$ & Valine \& pyrimidine metabolism & $-1.09,-1.04,-1.45,1.14$ \\
\hline Urate oxidase & P11645 & $1 E-111$ & Purine metabolism & $-1.08,-1.47,-1.41,-1.60$ \\
\hline Aspartate aminotransferase & P00504 & 0 & Amino acid catabolism & $1.16,-1.29,-1.96,1.18$ \\
\hline Glycine decarboxylase & P15505 & $2 E-10$ & Glycine catabolism & $1.24,-1.36,-1.89,1.38$ \\
\hline $\begin{array}{l}\text { Neutral and basic amino acid } \\
\text { transport protein rBAT }\end{array}$ & Q07837 & $6 E-85$ & Cystine reabsorption & $1.62,-1.14,-1.30,-1.22$ \\
\hline $\begin{array}{l}\text { Fructose-biphosphate } \\
\text { aldolase, muscle type }\end{array}$ & P53445 & $6 E-26$ & Glycolysis & $-1.26,-1.34,-1.61,-2.63$ \\
\hline $\begin{array}{l}\text { Cytochrome coxidase } \\
\text { subunit IV isoform } 2\end{array}$ & P80971 & $4 E-66$ & Mitochondrial respiration & $-1.27,-1.29,-1.69,-2.02$ \\
\hline $\begin{array}{l}\text { NADH-ubiquinone oxidoreductase } \\
\text { subunit B14.5b }\end{array}$ & Q9CQ54 & $7 E-19$ & Mitochondrial respiration & $1.37,-2.22,-1.92,1.74$ \\
\hline Hemopexin & P02790 & $2 E-44$ & Heme transport & $-1.22,-1.40,-2.08,-1.65$ \\
\hline $\begin{array}{l}\text { Solute carrier organic anion } \\
\text { transporter family member } 1 \mathrm{Cl}\end{array}$ & Q9EPZ7 & $1 E-23$ & Ion transport & $-1.02,-1.85,-1.39,-1.07$ \\
\hline Alcohol dehydrogenase 1 & P26325 & $3 E-92$ & $\begin{array}{l}\text { Oxidoreductase activity/xenobiotic } \\
\text { metabolism }\end{array}$ & $-1.07,-2.38,-2.63,-5.55$ \\
\hline 17- $\beta$-hydroxysteroid dehydrogenase 11 & Q6AYS8 & $4 \mathrm{E}-49$ & $\begin{array}{l}\text { Oxidoreductase activity/xenobiotic } \\
\text { metabolism }\end{array}$ & $1.53,-2.63,-1.82,2.07$ \\
\hline Cytochrome P450 1A1 & 042457 & 0 & $\begin{array}{l}\text { Oxidoreductase activity/xenobiotic } \\
\text { metabolism }\end{array}$ & $-1.72,-4.35,-2.00,-1.57$ \\
\hline Cytochrome P450 2J1 & P52786 & $3 \mathrm{E}-69$ & $\begin{array}{l}\text { Oxidoreductaseactivity/xenobiotic } \\
\text { metabolism }\end{array}$ & $1.02,-1.54,-1.06,-1.28$ \\
\hline Cytochrome P450 2J2 & P51589 & $7 E-63$ & $\begin{array}{l}\text { Oxidoreductaseactivity/xenobiotic } \\
\text { metabolism }\end{array}$ & $1.01,-1.59,1.02,-1.15$ \\
\hline Cytochrome P450 2J6 & O54750 & $2 \mathrm{E}-87$ & $\begin{array}{l}\text { Oxidoreductaseactivity/xenobiotic } \\
\text { metabolism }\end{array}$ & $1.34,-1.82,-2.00,-2.50$ \\
\hline Glutathione S-transferase 3 & P26697 & $2 \mathrm{E}-63$ & $\begin{array}{l}\text { Oxidoreductase activity/xenobiotic } \\
\text { metabolism }\end{array}$ & $-1.15,-1.79,-1.54,-1.89$ \\
\hline Monoamine oxidase & P49253 & $4 \mathrm{E}-66$ & $\begin{array}{l}\text { Oxidoreductaseactivity/xenobiotic } \\
\text { metabolism }\end{array}$ & $1.28,-1.82,-1.75,-1.59$ \\
\hline
\end{tabular}


Table 2: K-means clustering of down-regulated genes (Set 4). (Continued)

\begin{tabular}{|c|c|c|c|c|}
\hline $\begin{array}{l}\text { Retinol-binding protein II, } \\
\text { cellular }\end{array}$ & P50120 & $1 \mathrm{E}-51$ & $\begin{array}{l}\text { Oxidoreductaseactivity/xenobiotic } \\
\text { metabolism }\end{array}$ & $-1.23,-3.33,-3.03,-1.10$ \\
\hline a-2-HS-glycoprotein & Q9N2DO & $2 E-33$ & Acute immune response & $-1.13,-1.59,-1.85,-2.17$ \\
\hline Ig heavy chain Mem5 & P84751 & $4 E-38$ & Antigen binding & $-1.30,-1.07,1.03,-2.38$ \\
\hline $\begin{array}{l}\text { B-F histocompatibility } \\
\text { F10 antigen }\end{array}$ & P15979 & $4 E-41$ & Antigen processing & $-1.15,1.05,-1.45,-1.52$ \\
\hline $\begin{array}{l}\text { H-2 class II histocompatibility } \\
\text { antigen, A-K a chain }\end{array}$ & P01910 & $7 E-25$ & Antigen processing & $-1.28,-1.03,-1.30,-1.19$ \\
\hline Fucolectin-1 (lectin pathway) & Q91931 & $3 E-37$ & Complement activation & $1.04,-1.32,-1.35,-1.89$ \\
\hline Histamine $N$-methyltransferase & P50135 & $3 E-75$ & Histamine metabolism & $-1.08,-1.69,-1.53,-2.17$ \\
\hline Macrophage migration inhibitory factor & P80177 & $1 E-40$ & Inflammatory response & $-1.37,-1.37,-1.02,-1.48$ \\
\hline Interferon regulatory factor 8 & Q90871 & $1 E-15$ & Interferon signalling & $1.01,-1.67,-2.94,1.28$ \\
\hline Centaurin- $a 2$ & Q9NPF8 & $3 \mathrm{E}-28$ & GTPase activator & $-1.23,-1.37,-1.03,-2.22$ \\
\hline Collagen a $1(\mathrm{I})$ chain & P02457 & $4 \mathrm{E}-68$ & Collagen component & $1.43,-1.82,-1.72,-1.24$ \\
\hline Gastrulation-specific G12-like protein & Q9CQ20 & $4 \mathrm{E}-18$ & $\begin{array}{l}\text { Microtubule depolymerization, } \\
\text { inhibition }\end{array}$ & $-1.01,-1.79,-1.89,-1.08$ \\
\hline Plakophilin-3 & Q9QY23 & $8 \mathrm{E}-26$ & Cell adhesion & $-1.45,-1.67,-1.56,1.01$ \\
\hline Radixin & P26043 & $1 \mathrm{E}-24$ & Actin filament capping & $1.32,-3.23,-2.04,-1.83$ \\
\hline Transmembrane protein 59 & Q9QY73 & $8 \mathrm{E}-69$ & Membrane-bound protein & $-1.36,-1.41,-1.25,-2.08$ \\
\hline
\end{tabular}

Genes involved in similar pathways or processes are grouped and with the same font (italic/non-italic). 


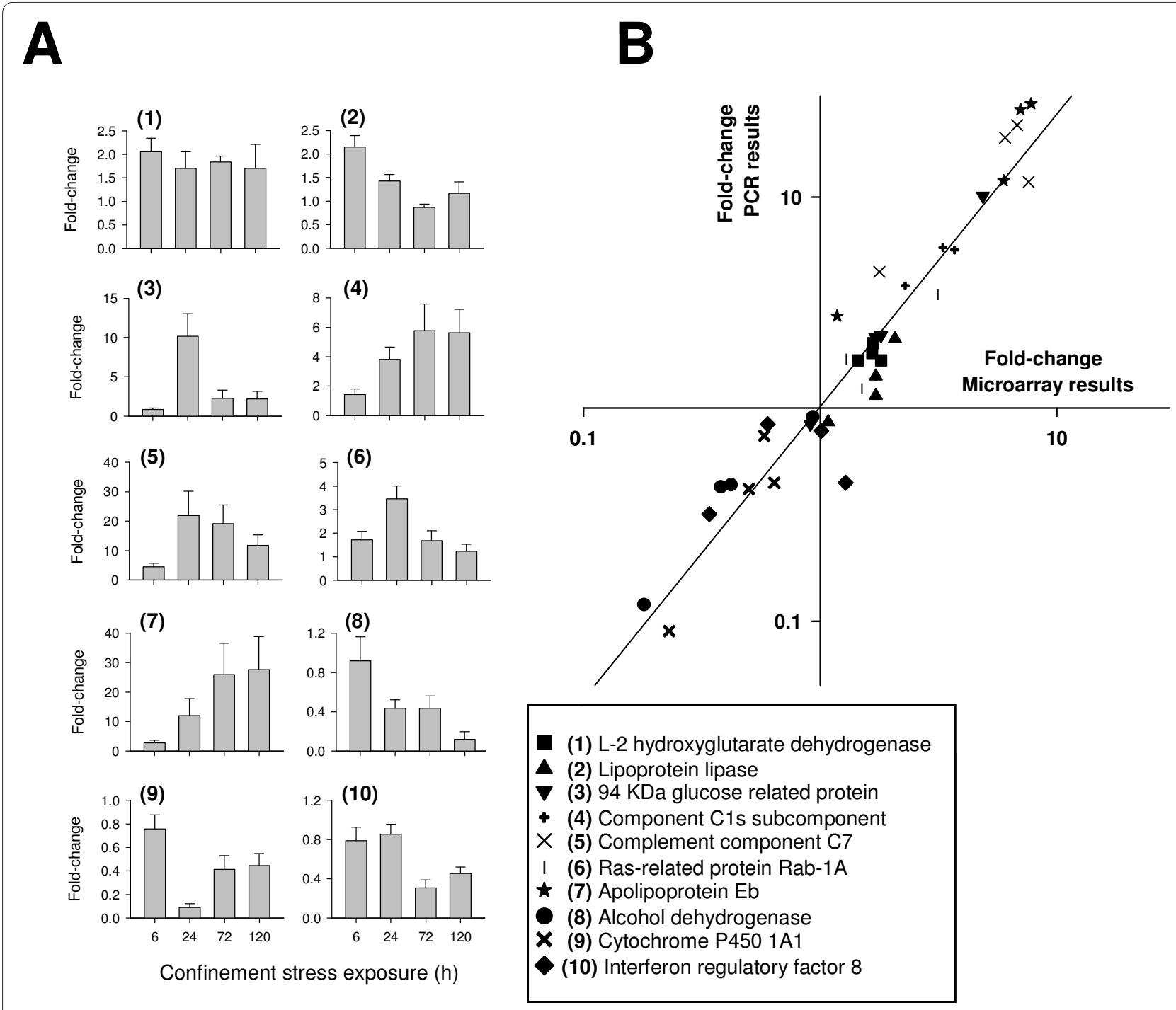

Figure 3 Real-time PCR validation of microarray results (A). Fold-change expression profiles of selected genes determined by real-time PCR. At each time point, bars indicate mean \pm SEM $(n=5)$. (B) Correlation plot of fold-change values (control vs stressed fish) for 10 selected genes (at 4 sampling times) analyzed by microarray (X-axis) and PCR methodologies (Y-axis).

In addition to LPL, other genes involved in lipid metabolism were up-regulated early at $6 \mathrm{~h}$ after stress confinement. Acid cholesteryl ester hydrolase, also termed lysosomal acid lipase, hydrolyzes triglycerides and cholesterol esters after lipoprotein endocytosis leading to increases in the cell availability of fatty acids as metabolic fuels. This up-regulation is in agreement with the observations made in mouse and zebrafish models, of enhancement of lysosomal acid lipase by heat shock [44] or hypoxia-associated stress [45]. In the present study, the up-regulation of lysosomal acid lipase coincided with the increased expression of heart-type fatty acid-binding protein. Members of this protein family act as intracellular transporters of fatty acids by trafficking their ligands via interactions with organelle membranes and specific proteins [46]. This transport system ensures a suit- able use of, and destination for fatty acids within the cell in each metabolic scenario. Therefore in our model, and perhaps others of increased energy demand, the up-regulation of cytoplasmic fatty acid binding proteins could facilitate the mitochondrial oxidation of fatty acids and may contribute to the protection of the cell against the lipotoxic effects of fatty acids in a changing and oxidative cellular environment. For instance, there are an increasing number of reports that deficiencies or altered functioning of both membrane-associated and cytoplasmic lipid binding proteins are associated with disease states, such as obesity, diabetes and atherosclerosis [47,48].

The transition from normal to stress conditions compromises cell survival and function and this fact could be in concordance with the early induction of apoptotic signals 


\section{SET 1(21 UP)}

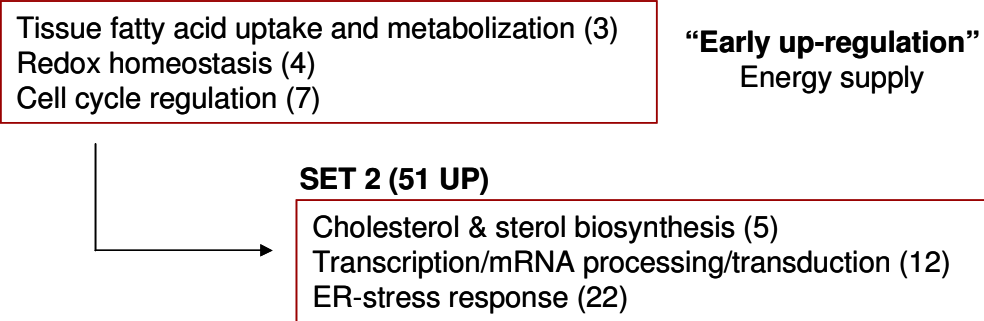

SET 2 (51 UP)

Cholesterol \& sterol biosynthesis (5)

Transcription/mRNA processing/transduction (12) ER-stress response (22)

"Early up-regulation" Energy supply

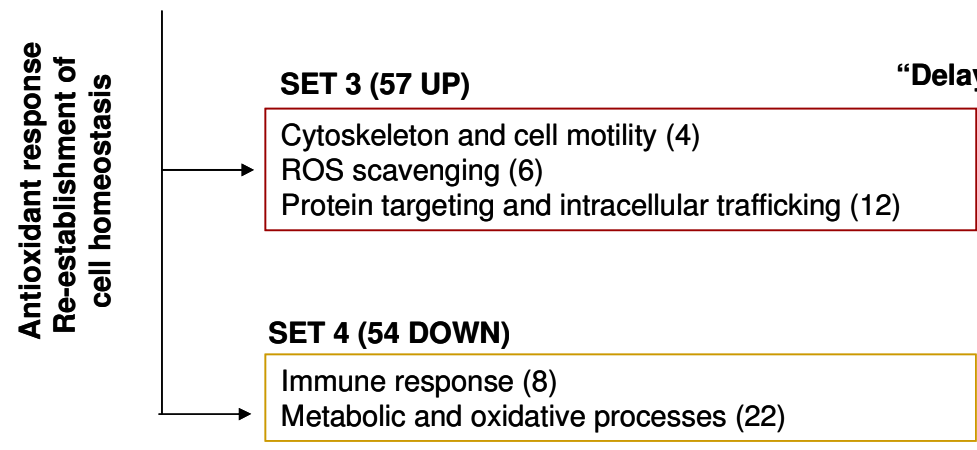

"Delayed and strong up-regulation" Tissue repair and remodelling

ed in parentheses.

(e.g. cell death-inducing DFFA-like effector protein C, ecto-ADP-ribosyltransferase 4) observed in this study. At the same time, however, the expression of several mitotic and cell proliferation factors (e.g. BolA-like protein 2, interferon-related developmental regulator 1) was enhanced, which could be indicative not only of redundant and overlapping genes but also of complex homeostatic adjustments to stress. Complex trade-off among apoptotic and proliferative factors were also in evidence when genes clustered in sets 2 and 3 were considered. Cell specific adjustments of apoptotic/proliferative pathways seem therefore to be a part of the complex time course of the stress response in gilthead sea bream in order to aid cellular homeostasis. This complex response has been described elsewhere in mammals and other fish species subsequent to toxicological, environmental and stress-disease challenges [49-53].

From our results it can also be concluded that cholesterol and sterol metabolism are transcriptionally mediated by stress confinement in gilthead sea bream. Indeed, several genes annotated with the GO-terms 'cholesterol biosynthetic process' and 'sterol biosynthetic process' belong to set 2 (arachidonate lipoxygenase 3, $\Delta$ (14)-sterol reductase, diphosphomevalonate decarboxylase, farnesyl diphosphate synthetase), to set 1 (cytochrome P450 3A10, estradiol 17$\beta$-dehydrogenase 1) and to set 3 (hydroxymethylglutarylCoA synthase). Since cortisol is a cholesterol-derived steroid, these transcriptional changes can be viewed as exten- sive processes aimed to maintain cortisol and steroid production in order to meet the needs of the stress response. As a matter of fact, a recently published study by SaeraVila et al. [12], with plasma samples coming from the present study, demonstrated a bimodal stress-response of cortisol with a fast and transient peak at $1.5 \mathrm{~h}$ followed by a second and more persistent peak at $24 \mathrm{~h}$ that would be nontranscriptionally- and transcriptionally-mediated, respectively. The same trend is found when only samples from animals used for microarray analysis are considered (Additional file 2). Similarly, Arends et al. [13] reported a bimodal cortisol response after handling and air exposure, which might highlight some initial exhaustion of the hypothalamic-pituitary-interrenal axis of gilthead sea bream when exposing fish to acute aquaculture stressors.

Also at $24 \mathrm{~h}$ after stress confinement, our results suggested the overall activation of transcriptional/translational machinery, possibly as part of the acute stress response to counteract oxidative stress and the associated cellular damage. Thus, chaperones (e.g. $94 \mathrm{kDa}$ glucose-regulated protein, $170 \mathrm{kDa}$ glucose-regulated protein and the cochaperone Hsp90) are clustered in set 2 and were strongly up-regulated in order to increase the cytoplasmic and ER protein folding capacity. ER chaperones assist the folding of nascent chains and help to achieve an active conformation for mature proteins [54]. In a process referred to as quality control only correctly folded proteins are exported to the Golgi complex, while incompletely folded proteins 
are retained in the ER to complete the folding process or be targeted for degradation [55,56]. ER-associated protein degradation (ERAD) is, therefore, a process that involves retrotranslocation into the cytosol and proteasome-mediated proteolysis. Ubiquitin, a major player in the proteasomal pathway of protein degradation, is stress activated in fish [57] and ubiquitin mRNA levels are increased after applying a handling stressor in rainbow trout [42]. However, the novel observation from our study is the increased abundance (set 2) of transcripts encoding for proteins involved in ERAD and ER translocation. Of interest later in the time course (set 3) is the dominance of transcripts encoding for extracellular $(\alpha-1$-microglobulin/bikunin precursor, a-2-macroglobulin) and proteasomal (Hsp70-binding protein 1, RWD domain-containing protein 1) inhibitors of proteolysis in addition to those involved in protein glycosylation, endocytosis and vesicle-mediated transport. Collectively, these findings provide evidence of shifts in protein breakdown and general protein synthesis leading to the complex homeostatic adjustments of protein metabolism to stress. Of particular interest is the up-regulation of clathrin and ras-related proteins which have an accepted role as vesicle-assembly proteins [58-60], although the physiological regulation of these proteins on intracellular protein transport and trafficking has not been reported yet in fish.

The enhanced expression of cytoskeleton and cell motility genes is also part of the late stress response that belongs to set 3 . These transcriptional-mediated effects are indicative of a general strategy to generate new cytoskeleton proteins for replacement of the degraded ones, or extensive cytoskeleton reorganization for overall tissue repair and remodeling processes [61]. This adaptive stress response also necessitates the late readjustment of the redox status, which involves a wide range of genes with oxido-reductase activity. Thus, among the genes clustered on set 3 , some play a cytoprotective role against oxidative insults promoting the synthesis of cysteine and reducing NADPH equivalents for glutathione synthesis and recycling. In addition, other genes promote the enhanced scavenging of reactive oxygen species (ROS). In this regard, the up-regulated expression of hemoglobin subunit $\beta$ and ferroxidase, also named ceruloplasmin, was of particular interest. Transcripts levels of $\alpha$ - and $\beta$-globin subunits of the hemoglobin $(\mathrm{Hb})$ molecule are increased in gilthead sea bream under extreme farming conditions [62], but the antioxidant effect may also be one of the essential functions of $\mathrm{Hb}$ when expressed in the non-erythroid cells of liver tissue. Indeed, the involvement of $\mathrm{Hb}$ in the protection of cells against nitrosative stress is a long-time recognized process [63], but $\mathrm{Hb}$ can also detoxify highly oxidizing radicals, yielding the ferric state as reported by Nishi et al. [64] in rat mesenglial cells. Likewise, ceruloplasmin is an important regulator of hepatic iron metabolism acting as well as a blood copper- carrier and ROS scavenger [65]. In fish, a cause-effect relationship has not yet been established, but the stress-mediated effects of ceruloplasmin in antioxidant defense are supported by its up-regulated expression not only in this, but also in other models of handling and confinement stress in rainbow trout [20] and of hypoxia-associated stress in cobia [66].

ROS production is inherent to aerobic metabolism and most of the beneficial effects of caloric restrictions are attributed to a reduced oxidative stress [67]. It is not surprising, therefore, that a reduced energy demand is one of the mechanisms operating in the adaptation to chronic stress [68]. For instance, glycolytic enzymes (fructosebiphosphate aldolase) and mitochondrial respiratory electron carriers (cytochrome c oxidase, NADH-ubiquinone) were down-regulated from $24 \mathrm{~h}$ through to $120 \mathrm{~h}$ (set 4). Liver is also the most important target tissue for detoxifying processes and the depletion of xenobiotic metabolism is also one of the potential ways to reduce ROS production [69]. In the present study, this notion is supported by the down-regulated expression of several enzymes of the cytochrome P450 family, which play a central role in the oxidative metabolism of many endogenous and exogenous substrates [70,71]. Among these, one of the most studied enzymes is CYP P450 1A1, which exhibits reduced expression in the liver of gilthead sea bream with reduced loadings of feed-borne contaminants [72]. Also, reduced expression is found in the liver of common dentex (Dentex dentex), a very stress susceptible fish of the Sparidae family, when mRNA transcript levels are compared to those found in gilthead sea bream [73]. Furthermore, our results indicate that retinol-binding protein, a known estrogenic biomarker [74,75], was persistently down-regulated over the course of stress confinement. As far as we know, there is no information in fish about the stress-mediated response of retinol-binding protein. However, the key role of this hepatic protein in fish vitellogenesis is well established [76,77], and its lowered expression could partly explain the impaired fish reproductive performance under confinement and extreme farming $[78,79]$.

Stress is reported to modulate the fish immune functions, although the net effect on the immune system is dependent on the intensity of the stressor. In the short term, acute stress may enhance both cellular and humoral components of fish innate defenses [80-82]. On the other hand, as glucocorticoid hormones such as cortisol have immunosuppressive effects, chronic stress is considered to be detrimental to fish immune function $[83,84]$. In the present work, stress adaptation after $24 \mathrm{~h}$ involves a complicated balance of upand down-regulation of genes that activate or suppress innate and adaptive immune functions (sets 3 and 4). Similar results have been reported in the liver transcriptome of rainbow trout after $3 \mathrm{~h}$ of low-water stress, with a downregulation of C-type lectins, and up-regulation of major his- 
tocompatibility complex components, interferon inducible proteins and complement factors [85]. Bearing in mind the potential that an immune response has as a source of ROS, this profile of expression for sea bream immune genes may reflect not only the maintenance of some specific immune functions, but also the necessity to prevent tissue-oxidative damage associated with a chronic stress condition.

\section{Conclusions}

In the present study we analyzed the time course of the stress response in gilthead sea bream and the results highlight early, delayed and persistent responses which lead to the attainment of a new steady state, and emphasize the complexity of the adaptive stress response. The ER is considered an important control point for the acute and homeostatic adjustments to stress, but later changes in energy demand, oxido-reductase activity and immunological competence are also envisaged. The microarray developed in this study will therefore be suitable for the transcriptional phenotyping of gilthead sea bream welfare and performance, Several studies, for example, are now underway for the multivariate analysis of stress dynamics in relation to nutrition, genotype and stress interactions. Preliminary results are highly promising and practical implications for a more robust and suitable evaluation of new fish feed formulations based on plant ingredients are now possible using these newly established genomic tools.

\section{Methods}

\section{Experimental setup}

Gilthead sea bream juveniles of 10-15 g initial body weight were randomly distributed in eight 500-1 tanks in a seawater re-circulatory system equipped with physical and biological filters, and a heat-unit system that maintained water temperature at $18-19^{\circ} \mathrm{C}$. Fish grew from July to December at a density of $8-10 \mathrm{~kg} / \mathrm{m}^{3}$ with an overall daily growth index $\left[\right.$ DGI $=100 \times\left(\right.$ final fish $\mathrm{wt}^{1 / 3}$ - initial fish $\left.\mathrm{wt}^{1 / 3}\right) /$ days $]$ of 1.9 \pm 0.01 . Voluntary feed intake was near to a maintenance ration at the time of the experiment (December), and it was stopped one day before confinement exposure to avoid result disturbances due to differences in feed intake between control (undisturbed fish) and stressed fish. Batches of 10 fish were then transferred from two 500-1 tanks to cylinder net baskets of 10-1 volume (117-123 Kg/ $\mathrm{m}^{3}$ ), suspended each one in 90-1 tanks with a high flow of seawater $(101 / \mathrm{min})$ to avoid water deterioration (Oxygen $>$ $5 \mathrm{ppm}$; unionized ammonia $<0.02 \mathrm{mg} / \mathrm{l})$. Fish from six additional 500-1 tanks were established as undisturbed control groups. No mortality was registered over the course of the experiment. Sampling times for tissue collection were established at 1.5, 3, 6, 24, 72 and $120 \mathrm{~h}$. Eight fish from one control and one confinement tank were netted into a bucket to be anaesthetized with $0.1 \mathrm{~g} / 1$ 3-aminobenzoic acid ethyl ester (MS-222) (Sigma, Saint Louis, MO, USA). Fish were killed by cervical section and selected tissues (brain, head kidney, gills and liver) were taken, frozen immediately in liquid nitrogen and stored at $-80^{\circ} \mathrm{C}$. Subsequently, tissue samples were thawed overnight in RNAlater-ICE (Ambion) and were stored at $-20^{\circ} \mathrm{C}$ until RNA isolation. All procedures were carried out according to national (Consejo Superior de Investigaciones Científicas, Institute of Aquaculture Torre de la Sal Review Board) and current EU legislation on the handling of experimental animals.

\section{RNA isolation}

Total RNA was prepared from tissues using a Qiazol and RNeasy Maxi Kit (Qiagen) combination protocol. On-column DNase treatment was incorporated to yield samples predominantly free of contaminating DNA. Total RNA was quantified by spectrophotometric measurements at $260 \mathrm{~nm}$ and their quality was analyzed with the Agilent 2100 bioanalyzer (Agilent Technologies). All samples met quality criteria with RNA integrity numbers between 7.5 and 10 , indicative of clean and intact RNA.

\section{Construction of SSH libraries}

Tissue samples from the confinement experiment were divided into "early" ( 1.5 and $3 \mathrm{~h}$ sampling time) and "late" $(24,72 \mathrm{~h})$ groups to construct $12 \mathrm{SSH}$ libraries: a) early and late liver libraries, b) early and late head kidney libraries, c) early brain libraries and d) early gill libraries. For each tissue and sampling group, two SSH libraries (forward and reverse) were made from pooled samples of mRNA from control or stressed fish. Four additional SSH libraries were constructed using head kidney and intestine tissue samples from healthy fish and fish infected with the myxosporean parasite Enteromyxum leei after 113 days of experimental pathogen exposure [86]. Transcripts of mRNA were purified from total RNA using an Oligotex mRNA Midi Kit (Qiagen). The mRNA populations were quantified by spectrophotometric measurements at $260 \mathrm{~nm}$. They were then analyzed for quality by denaturing agarose gel electrophoresis and probing of Northern blots with the housekeeping gene elongation factor $1-\alpha$.

Construction of SSH libraries was performed by means of the BD PCR Select cDNA Subtraction Kit (BD Biosciences Clontech). Two $\mu \mathrm{g}$ of mRNA were used from each sample to generate tester and driver cDNA. As described by the manufacturer, the cDNA was digested with Rsa I, tester cDNA was ligated to adaptors and the cDNAs were hybridized and PCR amplified. Aliquots $(1.5 \mu \mathrm{l})$ of secondary PCR products from subtracted cDNA populations were ligated to the pCR2.1 vector using the TA Cloning Kit (Invitrogen). Aliquots of ligation reactions were transformed into competent Top10 E. coli cells. Selected colonies (576-768) from each library were inoculated into 150 $\mu \mathrm{l}$ aliquots of LB kanamycin broth and duplicate glycerol stocks were stored at $-80^{\circ} \mathrm{C}$. Sequencing of SSH libraries 
(10,368 clones) was carried out at the Max Planck Institute of Molecular Genetics (Berlin, Germany), using ABI 3730XL (Applied Biosystems) and MegaBACE 4500 (GE Healthcare) capillary sequencer systems. All sequencing reactions were carried out with ABI BigDye Terminator version 3.1.

\section{Sequence assembly and analysis}

cDNA sequences from SSH libraries were combined with other available gilthead sea bream sequences in GenBank and EST collections (29,984 clones) made by the Consortium of Marine Genomics Europe. Sequences were edited to remove vector and adaptor sequences, cleaned and filtered before clustering and annotation by the SIGENAE information system (INRA Toulouse, France). Cleaning involved masking of poor quality bases and low complexity sequences such as polyA tails. Filtering removed contaminating sequences (bacteria, yeast) and only high quality sequences of more than 100 bases in length were retained. Contigs were annotated by comparison to the UniProt database using the BLASTX program http:// www.ncbi.nlm.nih.gov/BLAST/, and the entry to which they received the highest similarity was assigned as the gene identity. Gene ontology (GO) identifiers were obtained from the contig nucleotide sequences through the Blast2GO software [87] with a threshold cutoff at $10^{-3}$.

\section{PCR amplification and array printing}

The cDNA inserts of selected clones were amplified by PCR using adaptor-specific primers. Amplicons were then spotted onto Schott Nexterion slide E epoxy slides at the Max Planck Institute facilities. Each microarray consisted of PCR products from 18,490 cDNA clones printed in duplicate at $5 \mu \mathrm{m}$ resolution.

\section{RNA labeling and hybridization}

For microarray screening of the time course stress response, liver total RNA from 5 stressed and 5 control animals at each sampling time $(6,24,72$ and $120 \mathrm{~h})$ after confinement exposure were individually analyzed. A reference design approach was taken for the study: all experimental samples were labeled with one of the two dyes (Cy5 or $\mathrm{Cy} 3)$ and compared to a common reference sample (a pool of all the RNA samples used in the design) labeled with the second dye. Each hybridization experiment included dye swaps to compensate for cyanine dye effects, making a total of 80 microarray slides for the entire analysis. Denatured samples of total RNA $(10 \mu \mathrm{g})$ were reversed transcribed and indirectly labeled with $\mathrm{Cy} 5$ or $\mathrm{Cy} 3$ dyes using the SuperScript III Indirect cDNA Labeling System Kit (Invitrogen). Hybridizations were performed in a Genetix hybridization chamber and washes used the Advawash automatic washing station (Advalytix). Microarray slides were scanned in two channels $(543 \& 633 \mathrm{~nm})$ at $5 \mu \mathrm{m}$ resolution using a confocal laser scanner (ScanArray Express, Perkin Elmer).

\section{Microarray data analysis}

Two channel TIFF images were imported into the GenePix Pro 6 software program for feature (spot) finding and alignment using a batch alignment process. Features were flagged as present, absent or bad by this software program and pixel intensities for feature and background were quantified. Output GenePix results (GPR) files were imported into GeneSpring GX 7.3. Data was normalised for signal, dye swap and intensity (intensity dependent lowess normalisation) and $\log 10$ ratios of signal (experimental) to control (reference) channel were calculated. Data were filtered on confidence and signal strength. This experiment was placed in the NCBI Gene Expression Omnibus (GEO) as accession number GSE16633. One-way ANOVA by time and condition was performed to select those genes that were differentially expressed $(\mathrm{P}<0.05)$ between control/stress at least at one sampling point over the time course; expression profiles for these genes were clustered over the time course using the K-means algorithm. FatiGO software [88] was used to assess whether specific biological processes or molecular functions were over-represented in each cluster when compared to the others.

\section{PCR validation}

Microarray results were validated by real-time PCR of 10 target genes, selected to reflect the K-means clusters of upand down-regulated genes. cDNA was synthesized from 2.5 $\mu \mathrm{g}$ of total RNA and $500 \mathrm{ng}$ of polydT primer in a reaction volume of $40 \mu$ l, using SuperScript III reverse transcriptase (Invitrogen) following the supplier's protocol. Primers were designed for $\beta$-actin (housekeeping gene) and candidate genes (see Table 3) using Vector NTI Advance software (Invitrogen). The size of amplicons ranged between 100 and 150 base pairs and PCR reactions were set up as follows: $10 \mu \mathrm{l}$ of QuantiTect SYBR Green PCR Master Mix (Qiagen), $1 \mu \mathrm{l}$ of $10 \mu \mathrm{M}$ sense and antisense gene-specific primers, $5 \mu$ of cDNA template at a dilution of 1:12.5 and RNase-free water to a final volume of $20 \mu 1$. The MX3000P Real-time PCR system (Stratagene) was used for performing the amplification. The program used for PCR was $95^{\circ} \mathrm{C}$ for $15 \mathrm{~min}, 40$ cycles of $95^{\circ} \mathrm{C}$ for $15 \mathrm{~s}$, annealing at 51 $60^{\circ} \mathrm{C}$ for $30 \mathrm{~s}$ and extension at $72^{\circ} \mathrm{C}$ for $30 \mathrm{~s}$. Dissociation curves were examined at the end of the PCR reaction to check for unspecific amplification and primer-dimers.

To assess PCR efficiency, standard curves were created by serial dilution of cDNA preparations. Expression of the different samples was normalized to $\beta$-actin, and the efficiency of PCR reactions for target and reference genes varied between $88 \%$ and $95 \%$. Relative changes in the expression of candidate genes were calculated by the $\Delta \Delta \mathrm{C}_{\mathrm{t}}$ method [89]. 
Table 3: Primer sequences for quantitative PCR validation.

\begin{tabular}{ll} 
Gene name & Primer sequence \\
\hline L-2 hydroxyglutarate & FAAG GTC TTC ACA ATG ACA \\
dehydrogenase & ATG GCG \\
& RTCC CTC GCC ATC GCT GAA \\
AT
\end{tabular}

Lipoprotein lipase

F TIT ACG CTC TGT GAG GTC TCC GG

RGGG ACG TTG CCA AGTTTG TGA C

\begin{tabular}{ll}
\hline 94 KDa glucose related & F AGA ACG TGG CAA AGG \\
protein & AGG GTG T \\
& RTGT CCT TCA GGG CCT TGT \\
& CCT T
\end{tabular}

Complement $\mathrm{C} 1 \mathrm{~s}$ subcomponent

FCCC ACC CAG TGA TGA CTC CTG A

RGGC TTC CAG AAC CGATCT GAC TG

Complement component C7

F TTG ATT CCT GAC AGA CGG TCC CC

RCGG CTC AAC TCC ACC ACG TTा ACT T

Ras-related protein Rab-1A

F GCT GAA ATC AAG AAG AGG ATG GGC

R GAG TAA GAG GGC GGG GTG TCA A

Apolipoprotein Eb

FACT GAA CCA CTAAAA GTG CCC TTC T

RTAG CCG CAG GAC GTG CAT TTA

\begin{tabular}{ll}
\hline Alcohol dehydrogenase & F GTG CTG CAG TTT ATG GGA \\
& ACC AGT A \\
& R TAT TGA CTG CTG CTC CGT \\
& ATC CTG T
\end{tabular}

Cytochrome P450 1A1

FGCA TCA ACG ACC GCT TCA ACG C

R CCT ACA ACC TTC TCA TCC GAC ATC TGG

Interferon regulatory factor 8

F TGG AGG CAG TGA ACA TGC GG
Table 3: Primer sequences for quantitative PCR validation.

\begin{tabular}{ll}
\hline & RGGG CAT GTT GTC CTT GTA \\
& GCA GG \\
\hline 3-Actin & F CTG GAG AAG AGC TAT \\
& GAG CTG CCC \\
& RGGT GGT CTC ATG GAT TCC \\
& GCA G \\
\hline
\end{tabular}

\section{Additional material}

Additional file $1 \mathrm{~K}$-means clustering of up-regulated genes (Sets 1, 2, 3). Genes involved in similar pathways or processes are grouped and with the same font (italic/non-italic).

Additional file 2 Plasma cortisol levels of control (open circles) and stressed (filled circles) fish. Data are the mean \pm SEM $(n=5)$. Different letters indicate statistically significant changes over the course of the experiment in stressed fish (ANOVA, P < 0.05). Statistically significant differences between stressed and control fish were analyzed at each sampling time by means of Student t-test ( ${ }^{*} P<0.05$, $\left.{ }^{* *} P<0.01,{ }^{* * *} P<0.001\right)$.

\section{Authors' contributions}

JPS and PP conceived and designed the project. JACG, ASV, and JPS designed and performed the confinement experiment and sampled the experimental animals. GD and BH purified RNA from tissues and produced SSH libraries. JACG, GD, and BH performed microarray experiments. GD and MTC carried out all GenePix and GeneSpring analyses. JACG and JPS performed gene ontology analyses. ASV and AT validated array data by qRT-PCR. JACG and JPS wrote the manuscript. All listed authors edited the manuscript. All authors read and approved the final manuscript.

\section{Acknowledgements}

This work was funded by EU (SSP98-CT-2004-513692; Combined genetic and functional genomic approaches for stress and disease resistance marker assisted selection in fish and shellfish, AQUAFIRST) and Spanish (Ingenio-2010 Programme; Improvement of Aquaculture Production by the use of biotechnological tools, AQUAGENOMICS) projects. AS-V was recipient of a Spanish PhD fellowship from the Diputación Provincial de Castellón. The authors are grateful to M.A. González and Philippe Bardou for excellent technical assistance.

\section{Author Details}

'Fish Nutrition and Growth Endocrinology Group, Department of Biology, Culture and Pathology of Marine Fish Species, Institute of Aquaculture Torre de la Sal (CSIC), 12595 Ribera de Cabanes, Castellón, Spain, ${ }^{2}$ Martin Ryan Institute, National University of Ireland, Galway, Ireland and 3INRA-SCRIBE, Fish Adaptation and Stress Group, IFR Reproduction, Development and Ecophysiology, Rennes Cedex, France

Received: 17 September 2009 Accepted: 22 March 2010 Published: 22 March 2010

\section{References}

1. Mormède P, Courvoisier H, Ramos A, Marissal-Arvy N, Ousuva O, Désautés C, Duclos M, Chaouloff F, Moisan MP: Molecular genetic approaches to investigate individual variations in behavioral and neuroendocrine stress responses. Psychoneuroendocrinology 2002, 27:563-583.

2. Vandeputte $M$, Launey $S$ : The genetic management of fish domestication. Prod Anim 2004, 17:237-242.

3. Cnaani A: Genetic perspective on stress response and disease resistance in aquaculture. Israeli J Aquacult 2006, 58:375-383.

4. Fevolden SE, Refstie T, Gjerde B: Genetic and phenotypic parameters for cortisol and glucose stress response in Atlantic salmon and rainbow trout. Aquaculture 1993, 118:205-216. 
5. Fevolden SE, Røed KH, Fjalestad KT, Stien J: Poststress levels of lysozyme and cortisol in adult rainbow trout: heritabilities and genetic correlations. J Fish Biol 1999, 54:900-910.

6. Pottinger TG, Moran TA: Differences in plasma cortisol and cortisone dynamics during stress in two strains of rainbow trout (Oncorhynchus mykiss). J Fish Biol 1993, 43:121-130.

7. Pottinger TG, Carrick TR: Modification of the plasma cortisol response to stress in rainbow trout by selective breeding. Gen Comp Endocrinol 1999, 116:122-132.

8. Pottinger TG: Context dependent differences in growth of two rainbow trout (Oncorhynchus mykiss) lines selected for divergent stress responsiveness. Aquaculture 2006, 256:140-147.

9. Tanck MWT, Vermeulen KJ, Bovenhuis H, Komen H: Heredity of stressrelated cortisol response in androgenetic common carp (Cyprinus carpio L. Aquaculture 2001, 199:283-294.

10. Rotllant J, Montero D, Caballero MJ, Robaina L, Izquierdo MS, Tort L: Differences in interrenal tissue, biosynthetic capacity and ACTH sensitivity in progeny of sea bream from parents selected for high or low cortisol response. J Fish Biol 2003, 62:744-748.

11. Tort L, Montero D, Robaina L, Fernández-Palacios H, Izquierdo MS Consistency of stress response to repeated handling in the gilthead sea bream Sparus aurata. Aquacult Res 2001, 32:593-598.

12. Saera-Vila A, Calduch-Giner JA, Prunet P, Pérez-Sánchez J: Dynamics of liver GH/IGF axis and selected stress markers in juvenile gilthead sea bream (Sparus aurata) exposed to acute confinement. Differential stress response of growth hormone receptors. Comp Biochem Physiol A 2009, 154:197-203.

13. Arends RJ, Mancera J, Muñoz J, Wendelaar Bonga SE, Flick G: The stress response of gilthead sea bream (Sparus aurata $\mathrm{L}$ ) to air exposure and confinement. JEndocrinol 1999, 143:23-31.

14. Bermejo-Nogales A, Benedito-Palos L, Saera-Vila A, Calduch-Giner JA, SitjàBobadilla A, Pérez-Sánchez J: Confinement exposure induces glucose regulated protein 75 (GRP75/mortalin/mtHsp70/PBP74/HSPA9B) in the hepatic tissue of gilthead sea bream (Sparus aurata L. Comp Biochem Physiol B 2008, 149:428-438.

15. Saera-Vila A, Calduch-Giner JA, Pérez-Sánchez J: Co-expression of IGFs and GH receptors (GHRs) in gilthead sea bream (Sparus aurata L.): sequence analysis of the GHR-flanking region. J Endocrinol 2007, 194:361-372.

16. Miller KM, Maclean N: Teleost microarrays: development in a broad phylogenetic range reflecting diverse applications. J Fish Biol 2008, 72:2039-2050

17. Von Schalburg KR, Rise ML, Cooper GA, Brown GD, Gibbs AR, Nelson CC, Davidson WS, Koop BF: Fish and chips: Various methodologies demonstrate utility of a 16,006-gene salmonid microarray. BMC Genomics 2005, 6:126.

18. MacKenzie S, Iliev D, Liarte C, Koskinen H, Planas JV, Goetz FW, Mölsä H, Krasnov A, Tort L: Transcriptional analysis of LPS-stimulated activation of trout (Oncorhynchus mykiss) monocyte/macrophage cells in primary culture treated with cortisol. Mol Immunol 2006, 43:1340-1348.

19. Taggart JB, Bron JE, Martin SAM, Seear PJ, Høyheim B, Talbot R, Carmicheal SN, Villeneuve LAN, Sweeney GE, Houlihan DF, Secombes CJ, Tocher DR, Teale AJ: A description of the origins, design and performance of the TRAITS-SGP Atlantic salmon Salmo salar L. CDNA microarray. J Fish Biol 2008, 72:2071-2094.

20. Panserat S, Kolditz C, Richard N, Plagnes-Juan E, Piumi F, Esquerré D, Médale F, Corraze G, Kaushik S: Hepatic gene expression profiles in juvenile rainbow trout (Oncorhynchus mykiss) fed fishmeal or fish oilfree diets. Br J Nutr 2008, 100:953-967.

21. Cairns MT, Johnson MC, Talbot AT, Pemmasani JK, McNeill RE, Houeix B, Sangrador-Vegas A, Pottinger TG: A cDNA microarray assessment of gene expression in the liver of rainbow trout (Oncorhynchus mykiss) in response to a handling and confinement stressor. Comp Biochem Physiol D 2008, 3:51-66.

22. Diab AM, Williams TD, Sabine VS, Chipman JK, George SG: The GENIPOL European flonder Platichthys flesus L. toxicogenomics microarray: application for investigation of the response to furunculosis vaccination. J Fish Biol 2008, 72:2154-2169.

23. Cerdà J, Mercadé J, Lozano JJ, Manchado M, Tingaud-Sequeira A, Astola A, Infante C, Halm S, Viñas J, Castellana B, Asensio E, Cañabate P, MartínezRodríguez G, Piferrer F, Planas JV, Prat F, Yúfera M, Durany O, Subirada F, Rosell E, Maes T: Genomic resources for a commercial flatfish, the
Senegalese sole (Solea senegalensis): EST sequencing, oligo microarray design, and development of the Soleamold bioinformatics platform. BMC Genomics 2008, 9:508

24. Liu Z, Li RW, Waldbieser GC: Utilization of microarray technology for functional genomics in ictalurid catfish. J Fish Biol 2008, 72:2377-2390.

25. Peatman E, Terhune J, Baoprasertkul P, Xu P, Nandi S, Wang S, Somridhivej $B$, Kucuktas H, Li P, Dunham R, Liu Z: Microarray analysis of gene expression in the blue catfish liver reveals early activation of the MHC class I pathway after infection with Edwardsiella ictaluri. Mol Immunol 2008, 45:553-566.

26. Sarropoulou E, Kotoulas G, Power DM, Geisler R: Gene expression profiling of gilthead sea bream during early development and detection of stress-related genes by the application of CDNA microarray technology. Physiol Genomics 2005, 23:182-191.

27. Ferraresso S, Vitulo N, Mininni AN, Romualdi C, Cardazzo B, Negrisolo E, Reinhardt R, Canario AVM, Patarnello T, Bargelloni L: Development and validation of a gene expression oligo microarray for the gilthead sea bream (Sparus aurata). BMC Genomics 2008, 9:580

28. Diatchenko L, Lau YF, Campbell AP, Chenchik A, Moqadam F, Huang B, Lukyanov S, Lukyanov K, Gurskaya N, Sverdlov ED, Siebert PD: Suppression substractive hybridization: A method for generating differentially regulated or tissue-specific CDNA probes and libraries. Proc Natl Acad Sci USA 1996, 93:6025-6030.

29. Pinto PIS, Teodósio HR, Galay-Burgos M, Power DM, Sweeney GE, Canario AVM: Identification of estrogen-responsive genes in the testis of sea bream (Sparus auratus) using suppression substractive hybridization. Mol Reprod Dev 2006, 73:318-329.

30. Dios S, Poisa-Beiro L, Figueras A, Novoa B: Suppression subtraction hybridization (SSH) and macroarray techniques reveal differential gene expression profiles in brain of sea bream infected with nodavirus. Mol Immunol 2007, 44:2195-2204.

31. Wendelaar Bonga SE: The stress response in fish. Physiol Rev 1997, 77:591-625.

32. Iwama GK, Afonso LOB, Vijayan MM: Stress in Fish. In The Physiology of Fishes Edited by: Evans DH, Claiborne JB. Boca Raton: CRC Press; 2006:319-342

33. Rotllant J, Balm PHM, Ruane NM, Pérez-Sánchez J, Wendelaar-Bonga SE, Tort L: Pituitary proopiomelanocortin-derived peptides and hypothalamus-pituitary-interrenal axis activity in gilthead sea bream (Sparus aurata) during prolonged crowding stress: differential regulation of adrenocorticotropin hormone and a-melanocytestimulating hormone release by corticotropin-releasing hormone and thyrotropin-releasing hormone. Gen Comp Endocrinol 2000, 119:152-163.

34. Rotllant J, Balm PHM, Pérez-Sánchez J, Wendelaar-Bonga SE, Tort L: Pituitary and interrenal function in gilthead sea bream (Sparus aurata L., teleostei) after handling and confinement stress. Gen Comp Endocrinol 2001, 121:333-342.

35. Barton $B A$, Ribas $L$, Acerete $L$, Tort $L$ : Effects of chronic confinement on physiological responses of juvenile githead sea bream, Sparus aurata L., to acute handling. Aquacult Res 2005, 36:172-179.

36. Mancera JM, Vargas-Chacoff L, García-López A, Kleszczyeska A, Kalamarz H, Martínez-Rodríguez G, Kulcykowska E: High density and food deprivation affect arginine vasotocin, isotocin and melatonin in gilthead sea bream (Sparus auratus). Comp Biochem Physiol A 2008, 149:92-97.

37. Sloman KA, Motherwell G, O Connor KI, Taylor AC: The effect of social stress on the Standard Metabolic Rate (SMR) of brown trout, Salmo trutta. Fish Physiol Biochem 2000, 23:49-53.

38. Watanabe T: Lipid nutrition in fish. Comp Biochem Physiol B 1982, 73:3-15.

39. Sargent JR, Tocher DR, Bell JG: The Lipids. In Fish Nutrition Edited by: Haver JE, Hardy RW. London: Academic Press; 2003:181-257.

40. Mead JR, Irvine SA, Ramji DP: Lipoprotein lipase: structure, function, regulation, and role in disease. J Mol Med 2002, 80:753-769.

41. Albalat A, Gómez-Requeni P, Rojas P, Médale F, Kaushik S, Vianen GJ, Thillart G Van der, Gutiérrez J, Pérez-Sánchez J, Navarro I: Nutritional and hormonal control of lipolysis in isolated gilthead sea bream (Sparus aurata) adipocytes. Am J Physiol 2005, 289:R259-R265.

42. Saera-Vila A, Calduch-Giner JA, Gómez-Requeni P, Médale F, Kaushik S, Pérez-Sánchez J: Molecular characterization of gilthead sea bream (Sparus aurata) lipoprotein lipase. Transcriptional regulation by season 
and nutritional condition in skeletal muscle and fat storage tissues. Comp Biochem Physiol B 2005, 142:224-232.

43. Wiseman S, Osachoff H, Bassett E, Malhotra J, Bruno J, VanAggelen G, Mommsen TP, Vijayan MM: Gene expression pattern in the liver during recovery from an acute stressor in rainbow trout. Comp Biochem Physiol D 2007, 2:234-244

44. Szustakowski JD, Kosinski PA, Marrese CA, Lee JH, Elliman SJ, Nirmala N, Kemp DM: Dynamic resolution of functionally related gene sets in response to acute heat stress. BMC Mol Biol 2007, 8:46.

45. Meer DLM Van der, Thillart GEEJM Van der, Witte F, de Bakker MAG, Besser J, Richardson MK, Spaink HP, Leito JTD, Bagowski CP: Gene expression profiling of the long-term adaptive response to hypoxia in the gills of adult zebrafish. Am J Physiol 2005, 289:R1512-R1519.

46. Storch J, Corsico B: The emerging functions and mechanisms of mammalian fatty-acid binding proteins. Ann Rev Nutr 2008, 28:73-95.

47. Glatz JFC, Luiken JJFP, Van Bilsen M, Vusse GJ Van der: Cellular lipid binding proteins as facilitators and regulators of lipid metabolism. $\mathrm{Mol}$ Cell Biochem 2002, 239:3-7.

48. Doege H, Stahl A: Protein-mediated fatty acid uptake: novel insights from in vivo models. Physiology 2006, 21:259-268.

49. Verburg-Van Kemenade BML, Nowak B, Engelsma MY, Weyts FAA: Differential effects of cortisol on apoptosis and proliferation of carp Blymphocytes from head kidney, spleen and blood. Fish Shellfish Immunol 1999, 9:405-415.

50. Kyriakis JM, Avruch J: Mammalian mitogen-activated protein kinase signal transduction pathways activated by stress and inflammation. Physiol Rev 2001, 81:807-869.

51. Krasnov A, Koskinen H, Pehkonen P, Rexroad CE III, Afanasyev S, Mölsä H: Gene expression in the brain and kidney of rainbow trout in response to handling stress. BMC Genomics 2005, 6:3.

52. Takeda K, Noguchi T, Naguro I, Ichijo H: Apoptosis signal-regulating kinase 1 in stress and immune response. Ann Rev Pharmacol 2008, 48:199-225.

53. Franco R, Sánchez-Olea R, Reyes-Reyes EM, Panayiotidis MI: Environmental toxicity, oxidative stress and apoptosis: Ménage à trois. Mut Res 2009, 674:3-22.

54. Ma Y, Hendershot LM: The role of the unfolded protein response in tumour development: friend or foe? Nat Rev Cancer 2004, 4:966-977.

55. Schröder M, Kaufman RJ: The mammalian unfolded protein response. Ann Rev Biochem 2005, 74:739-789.

56. Meusser B, Hirsch C, Jarosch E, Sommer T: ERAD: the long road to destruction. Nat Cell Biol 2005, 7:766-772.

57. Ryan SN, Pankhurst NW, Wells RMG: A possible role for ubiquitin in the stress response of the teleost fish blue mao mao (Scorpis violaceus). Physiol Zool 1995, 68:1077-1092.

58. Wittinghofer A, Nassar N: How Ras-related proteins talk to their effectors. Trends Biochem Sci 1996, 21:488-491.

59. Hancock JF, Parton RG: Ras plasma membrane signalling platforms. Biochem J 2005, 389:1-11.

60. Wolfe BL, Trejo J: Clathrin-dependent mechanisms of G protein-coupled receptor endocytosis. Traffic 2007, 8:462-470.

61. Pedersen SF, Hoffmann EK, Mills JW: The cytoskeleton and cell volume regulation. Comp Biochem Physiol A 2001, 130:385-399.

62. Campo S, Nastasi G, D Ascola A, Campo GM, Avenoso A, Traina P, Calatroni A, Burrascano E, Ferlazzo A, Lupidi G, Gabbianelli R, Falcioni G: Hemoglobin system of Sparus aurata : changes in fishes farmed under extreme conditions. Sci Total Environ 2008, 403:148-153.

63. Hausladen A, Gow AJ, Stamler JS: Nitrosative stress: metabolic pathway involving the flavohemoglobin. Proc Natl Acad Sci USA 1998, 95:14100-14105.

64. Nishi H, Inagi R, Kato H, Tanemoto M, Kojima I, Son D, Fujita T, Nangaku M: Hemoglobin is expressed by mesangial cells and reduces oxidant stress. J Am Soc Nephrol 2008, 19:1500-1508.

65. Cousins RJ: Absorption, transport, and hepatic metabolism of copper and zinc: special reference to metallothionein and ceruloplasmin Physiol Rev 1985, 65:238-309.

66. Cnaani A, McLean E: Time-course response of cobia (Rachycentron canadum) to acute stress. Aquaculture 2009, 289:140-142.

67. Gredilla R, Barja G: The role of oxidative stress in relation to caloric restriction and longevity. Endocrinology 2005, 146:3713-3717.

68. Staples JF, Buck LT: Matching cellular metabolic supply and demand in energy-stressed animals. Comp Biochem Physiol A 2009, 153:95-105.
69. Valavanidis A, Vlahogianni T, Dassenakis M, Scoullos M: Molecular biomarkers of oxidative stress in aquatic organisms in relation to toxic environmental pollutants. Ecotoxicol Environ Saf 2006, 64:178-189.

70. Nelson DR, Koymans L, Kamataki T, Stegeman JJ, Feyereisen R, Waxman DJ, Waterman MR, Gotoh O, Coon MJ, Estabrook RW, Gunsalus IC, Nebert DW: P450 superfamily: update on new sequences, gene mapping, accession numbers and nomenclature. Pharmacogenetics 2006, 6:1-42.

71. Hannemann F, Bichet A, Ewen KM, Bernhardt R: Cytochrome P450 systems-biological variations of electron transport chains. Biochim Biophys Acta 2007, 1770:330-344

72. Saera-Vila A, Benedito-Palos L, Sitjà-Bobadilla A, Nácher-Mestre J, Serrano R, Kaushik S, Pérez-Sánchez J: Assessment of the health and antioxidant tradeoff in gilthead sea bream (Sparus aurata L.) fed alternative diets with low contaminants. Aquaculture in press.

73. Bermejo-Nogales A, Saera-Vila A, Calduch-Giner JA, Navarro JC, SitjàBobadilla A, Pérez-Sánchez J: Differential metabolic and gene expression profile of juvenile common dentex (Dentex dentex $\mathrm{L}$.) and gilthead sea bream (Sparus aurata L.) in relation to redox homeostasis. Aquaculture 2007, 267:213-224

74. Levy G, Lutz I, Krüger A, von Tümpling W, Kloas W: Retinol-binding protein as a biomarker to assess endocrine-disrupting compounds in the environment. Anal Bioanal Chem 2004, 378:676-683.

75. Li XH, Kakkad B, Ong DE: Estrogen directly induces expression of retinoic acid biosynthetic enzymes, compartmentalized between the epithelium and underlying stromal cells in rat uterus. Endocrinology 2004, 145:4756-4762.

76. Sammar M, Babin PK, Durliat M, Meiri I, Zchori I, Elizur A, Lubzens E: Retinol binding protein in rainbow trout: molecular properties and $\mathrm{mRNA}$ expression in tissues. Gen Comp Endocrinol 2001, 123:51-61.

77. Von Schalburg KR, Rise ML, Brown GD, Davidson WS, Koop BF: A comprehensive survey of the genes involved in maturation and development of the rainbow trout ovary. Biol Reprod 2005, 72:687-699.

78. Campbell PM, Pottinger TG, Sumpter JP: Preliminary evidence that chronic confinement stress reduces the quality of gametes produced by brown and rainbow trout. Aquaculture 1994, 120:151-169.

79. Schreck CB, Contreras-Sanchez W, Fitzpatrick MS: Effects of stress on fish reproduction, gamete quality, and progeny. Aquaculture 2001, 197:3-24

80. Demers NE, Bayne CJ: The immediate effects of stress on hormones and plasma lysozyme in rainbow trout. Dev Comp /mmunol 1997. 21:363-373

81. Ruis MAW, Bayne CJ: Effects of acute stress on blood clotting and yeast killing by phagocytes of rainbow trout. J Aquat Anim Health 1997, 9:190-195.

82. Fast MD, Hosoya S, Johnson SC, Afonso LOB: Cortisol response and immune-related effects of Atlantic salmon (Salmo salar Linnaeus) subjected to short- and long-term stress. Fish Shellfish Immunol 2008, 24:194-204

83. Pickering AD, Pottinger TG: Stress response and disease resistance in salmonid fish: effects of chronic elevation of plasma cortisol. Fish Physiol Biochem 1989, 7:253-258.

84. Yin Z, Lam J, Sin YM: The effects of crowding stress on the non-specific immune response in fancy carp (Cyprinus carpio L.). Fish Shellfish Immunol 1995, 5:519-529.

85. Momoda TS, Schwindt AR, Feist GW, Gerwick L, Bayne CJ, Schreck CB: Gene expression in the liver of rainbow trout, Oncorhynchus mykiss, during the stress response. Comp Biochem Physiol D 2007, 2:303-315.

86. Sitjà-Bobadilla A, Calduch-Giner J, Saera-Vila A, Palenzuela O, ÁlvarezPellitero P, Pérez-Sánchez J: Chronic exposure to the parasite Enteromyxum leei (Myxozoa: Myxosporea) modulates the immune response and the expression of growth, redox and immune relevant genes in gilthead sea bream, Sparus aurata L. Fish Shellfish Immunol 2008, 24:610-619.

87. Conesa A, Götz S, García-Gómez JM, Perol J, Talón M, Robles M: Blast2GO: a universal tool for annotation, visualization and analysis in functional genomics research. Bioinformatics 2005, 21:3674-3676.

88. Al-Shahrour F, Diaz-Uriarte R, Dopazo J: FatiGO: a web tool for finding significant associations of Gene Ontology terms with groups of genes. Bioinformatics 2004, 20:578-580.

89. Livak KJ, Schmittgen TD: Analysis of relative gene expression data using real-time quantitative PCR and the 2- CT method. Methods 2001, 25:402-408 

and take full advantage of:

- Convenient online submission

- Thorough peer review

- No space constraints or color figure charges

- Immediate publication on acceptance

- Inclusion in PubMed, CAS, Scopus and Google Scholar

- Research which is freely available for redistribution 